\title{
STUDI PERKUATAN GEOTEXTILE PADA LERENG DENGAN VARIASI KEMIRINGAN DAN JARAK PONDASI DANGKAL MELALUI PEMODELAN DI LABORATORIUM
}

\author{
Edo Caraka Yodha ${ }^{1}$, Arief Alihudien ${ }^{2}$, Pujo Priyono ${ }^{3}$ \\ Program Studi Teknik Sipil, Fakultas Teknik, Universitas Muhammadiyah Jember 1,2,3 \\ J1. Karimata 49, Jember 68121, Indonesia \\ email: edo.caka@yahoo.com
}

\begin{abstract}
Indonesia is a country in the developing period where the infrastructure that is built cannot be separated from sloping land or slopes, such as housing construction and making Embankments for Toll roads. Responding to this incident the authors conducted an analysis of slope stability with and without reinforcement through modeling in the laboratory. There are several types of soil reinforcement, one of which uses Geotextile reinforcement, the use of Geotextile can increase slope stability. This study aims to determine the stability of the slope to the effect of three variations in the distance of shallow foundation loading and three variations of the slope. Tests in this study are divided into 2 types of models, namely: (1) Testing Model I is a test of 2 variations of loading distance and 3 variations of soil slope without using reinforcement Gotextile Woven (2) Testing of Model II is a test of 2 variations of loading distance and 3 variations of soil slope by using Gotextile Woven reinforcement. In the review of 3 (three) variations in slope, namely: $45^{\circ}, 50^{\circ}$, and $60^{\circ}$ and 2 (two) variations in the distance of loads that work on the slope, namely: $4 \mathrm{~cm}$ and $7 \mathrm{~cm}$. In modeling the soil before being repaired using Geotextile it can be seen that the smaller the slope angle, the carrying capacity of the soil which is correlated with the stiffness of the soil is of great value. While in soil modeling after being repaired using Geotextile the smaller the slope angle, the carrying capacity of the soil which is correlated with the stiffness of the soil is of little value. In soil modeling before being repaired using Geotextile, it can be seen that the farther the loading distance from the lip of the slope, the carrying capacity of the soil which is correlated with the stiffness of the soil is of great value. While in soil modeling after being repaired using Geotextile the farther the loading distance from the lip of the slope, the carrying capacity of the soil which is correlated with the stiffness of the soil is of little value. It can be analogized that the improvement of slope land using Geotextile has the property of reinforcing the soil where the greater the slope angle the more rigid.
\end{abstract}

Keywords: Research, Stability, Geotextile Woven, slope variation, variation of loadingdistance.

\begin{abstract}
Abstrak
Indonesia merupakan negara dalam masa berkembang pembangunannya dimana prasarana yang dibangun tidak lepas dari tanah bidang miring atau lereng, seperti pembangunan perumahan dan pembuatan Embankment untuk jalan Tol. Menyikapi kejadian ini penulis melakukan analisa stabilitas lereng dengan dan tanpa perkuatan melalui pemodelan di laboratorium. Ada beberapa jenis perkuatan tanah, salah satunya menggunakan perkuatan Geotextile, penggunaan Geotextile dapat meningkatkan stabilitas lereng. Penelitian ini bertujuan untuk mengetahui stabilitas lereng terhadap pengaruh tiga variasi jarak pembebanan pondasi dangkal dan tiga variasi kemiringan lereng. Pengujian dalam penelitian ini dibedakan menjadi 2 macam model yaitu: (1) Pengujian Model I merupakan uji 2 variasi jarak pembebanan dan 3 variasi kemiringan tanah tanpa menggunakan perkuatan Gotextile Woven (2) Pengujian Model II merupakan uji 2 variasi jarak pembebanan dan 3 variasi kemiringan tanah dengan menggunakan perkuatan Gotextile Woven. Di tinjauan dari 3 (tiga) variasi kemiringan, yaitu: $45^{\circ}, 50^{\circ}$, dan $60^{\circ}$ serta 2 (dua) variasi jarak beban yang bekerja pada lereng, yaitu: $4 \mathrm{~cm}$ dan $7 \mathrm{~cm}$. Pada pemodelan tanah sebelum diperbaiki menggunakan Geotextile dapat diketahui bahwa semakin kecil sudut kelerengannya, maka daya dukung tanah yang
\end{abstract}


dikorelasikan dengan kekakuan tanah bernilai besar. Sedangkan pada pemodelan tanah sesudah diperbaiki menggunakan Geotextile semakin kecil sudut kelerengannya, maka daya dukung tanah yang dikorelasikan dengan kekakuan tanah bernilai kecil. Pada pemodelan tanah sebelum diperbaiki menggunakan Geotextile dapat diketahui bahwa semakin jauh jarak pembebanan dari bibir lereng, maka daya dukung tanah yang dikorelasikan dengan kekakuan tanah bernilai besar. Sedangkan pada pemodelan tanah sesudah diperbaiki menggunakan Geotextile semakin jauh jarak pembebanan dari bibir lereng, maka daya dukung tanah yang dikorelasikan dengan kekakuan tanah bernilai kecil. Dapat di analogikan bahwa perbaikan tanah lereng dengan menggunakan Geotextile mempunyai sifat memperkaku tanah yang mana semakin besar sudut kelerengan maka semakin kaku.

Kata kunci: Penelitian, Stabilitas, Geotextile Woven, variasi kemiringan, variasi jarak pembebanan.

\section{PENDAHULUAN}

\subsection{Latar belakang}

Indonesia merupakan negara dalam masa berkembang pembangunannya dimana prasarana yang dibangun tidak lepas dari tanah bidang miring atau lereng, seperti pembangunan perumahan dan pembuatan Embankment untuk jalan Tol. Menyikapi kejadian ini penulis melakukan analisa stabilitas lereng dengan dan tanpa perkuatan melalui pemodelan di laboratorium. Ada beberapa jenis perkuatan tanah, salah satunya menggunakan perkuatan Geotextile, penggunaan Geotextile dapat meningkatkan stabilitas lereng. Penelitian ini bertujuan untuk mengetahui stabilitas lereng terhadap pengaruh tiga variasi jarak pembebanan pondasi dangkal dan tiga variasi kemiringan lereng.

\subsection{Rumusan Masalah}

Berdasarkan latar belakang di atas maka dapat disusun perumusan masalah sebagai berikut:

1. Bagaimana stabilitas tanah akibat pengaruh kemiringan lereng dengan dan tanpa perkuatan Geotextile Woven melalui pemodelan di laboratorium ?

2. Bagaimana stabilitas tanah akibat pengaruh jarak beban pondasi dangkal dengan dan tanpa perkuatan Geotextile Woven melalui pemodelan di laboratorium?

\subsection{Tujuan}

Adapun tujuan penelitian dari tugas akhir ini adalah:

1. Untuk mengetahui stabilitas tanah akibat pengaruh kemiringan lereng dengan dan tanpa perkuatan Geotextile

Woven melalui pemodelan di laboratorium.

2. Untuk mengetahui stabilitas tanah akibat pengaruh jarak beban pondasi dangkal dengan dan tanpa perkuatan Geotextile Woven melalui pemodelan di laboratorium.

\subsection{Batasan Masalah}

Untuk memperjelas dari fokus penelitian ini, maka ruang lingkup permasalahan dibatasi sebagai berikut:

1. Data tanah yang digunakan adalah data tanah yang diambil sampelnya hanya pada lokasi yang ditentukan

2. Dalam penelitian ini hanya menggunkan parameter tanah sebagai berikut:

\begin{tabular}{|c|c|}
\hline$\Upsilon \mathrm{d}$ & $=1,78 \mathrm{gr} / \mathrm{cm} 3$ \\
\hline Wopt & $=10,5 \%$ \\
\hline$\varphi$ & $=41,11^{\circ}$ \\
\hline c & $=0,09$ \\
\hline
\end{tabular}

3. Menggunakan 3 lapis Geotextile Woven panjang $15 \mathrm{~cm}$ dengan tinggi tanah pemodelan $12 \mathrm{~cm}$.

4. Menggunakan 3 variasi sudut kemiringan, yaitu $45^{\circ}, 50^{\circ}$, dan $60^{\circ}$.

5. Menggunakan variasi 2 jarak beban pondasi dangkal, yaitu $4 \mathrm{~cm}$ dan $7 \mathrm{~cm}$.

6. Analisa keruntuhan hanya di modelkan di laboratorium.

\subsection{Tinjauan Pustaka}

\section{Lereng}

Lereng merupakan bagian dari permukaan bumi yang memiliki sudut kemiringan tertentu dengan bidang datar (horizontal). Lereng dapat 
terjadi secara alami ataupun karena buatan manusia dengan tujuan tertentu. Wesley (1977) membagi lereng menjadi 3 macam ditinjau dari segi terbentuknya, yaitu :

1. Lereng alam,

2. Lereng yang dibuat dari tanah asli,

3. Lereng yang dibuat dari tanah yang dipadatkan,

\section{Longsoran}

Tanah longsor (longsoran) adalah pergerakan massa tanah atau batuan ke arah miring, mendatar, atau vertikal pada salah satu lereng. Longsor terjadi karena terganggunya keseimbangan lereng akibat pengaruh gaya gaya yang berasal dari dalam lereng seperti gaya gravitasi bumi, tekanan air pori dalam tanah atau lereng, dan gaya dari luar lereng seperti getaran kendaraan dan pembebanan kendaraan. Terzaghi (1950, dalam Hardiyatmo, 2003 : 326) membagi penyebab longsoran lereng terdiri dari akibat pengaruh dalam (internal effect) dan pengaruh luar (external effect).

\section{Pondasi dangkal}

Sampai saat ini masih sulit bagi kita untuk mendefinisikan pondasi dangkal, karena sangat tergantung dari masing-masing ahli tanah yang menginterprestasikan. Sebagai contoh Terzaghi mendefinisikan pondasi dangkal sebagai berikut:

1. Apabila kedalaman pondasi lebih kecil atau sama dengan lebar pondasi, maka pondasi tersebut bisa dikatakan sebagai pondasi dangkal.

2. Anggapan bahwa penyebaran daya dukung pada struktur pondasi ke tanah dibawahnya yang berupa lapisan penyangga (bearing stratum) lebih kecil atau sama dengan lebar pondasi.

Pada umumnya pondasi dangkal berupa pondasi telapak yaitu pondasi yang mendukung bengunan secara langsung pada tanah pondasi, bilamana terdapat lapisan tanah yang cukup tebal dan berkualitas baik yang mampu mendukung suatu bangunan pada permukaan tanah.

\section{Geotextile}

Geotextile merupakan suatu bahan sintetis permeable yang terbuat dari bahan tekstil polimer seperti polyester atau polypropylene. Untuk dipakai dalam memisahkan, menyaring, memperkuat, melindungi dan menguras jika digunakan didalam tanah. Geotextile memisahkan tanah mendasari permukaan. Geotextile ada dua macam yaitu Geotextile Woven dan Geotextile Non Woven:

\section{Geotextile Woven}

Tipe ini merupakan jenis Geotextile yang dibuat dengan cara menganyam dua set atau lebih elemen, seperti benang, fiber, pita, atau filamen dimana elemen ini saling bertautan biasanya pada sudut yang sesuai. Bahan dasar untuk pembuatan umumnya Polypropilene (PP). Untuk mempermudah visualisasi, Geotextile Woven ini mirip dengan karung beras tetapi warna hitam.

Fungsi Geotextile Woven yaitu sebagai bahan stabilisasi tanah dasar (terutama pada tanah dasar lunak), dikarenakan Geotextile jenis ini mempunyai tensile strength (kuat tarik) yang lebih tinggi dibandingkan dengan Geotextile Non Woven (kurang lebih sekitar 2 kali lipat untuk gramasi atau berat per $\mathrm{m}^{2}$ yang sama).

\section{Geotextile Non Woven}

Tipe ini merupakan jenis Geotextile Non Woven dari struktur benang tidak beraturan, disatukan dengan proses bonding, interlocking, atau keduanya secara mekanik, kimiawi, thermal, solvent, atau kombinasinya sehingga berbentuk seperti karpet kain. Biasanya bahan dasarnya terbuat dari bahan polimer Polyesther (PET) atau Polypropylene (PP). fungsi Geotextile Non Woven adalah membrane effect, yang hanya mengandalkan tensil strength, sehingga tidak mereduksi terjadinya penurunan setempat (differensial settlement) akibat tanah dasar yang lunak atau kurang baik.

\section{Parameter Bearing Capacity Improvement (BCI)}

"Bearing Capacity Improvement" arti dalam Bahasa Indonesia "peningkatan kapasitas daya dukung" atau disingkat dengan BCI merupakan parameter untuk meninjau peningkatan kapasitas daya dukung tanah sesudah diberi perkuatan menggunakan 
Geotextile Woven dengan kapasitas daya dukung tanah sebelum diberi perkuatan menggunakan Geotextile Woven.

\subsection{Hipotesis Penelitian}

H1 = terdapat pengaruh positif variasi kemiringan terhadap stabilitas lereng sebelum diperbaiki dengan Geotextile Woven.

H2 = terdapat pengaruh negatif variasi kemiringan terhadap stabilitas lereng sebelum diperbaiki dengan Geotextile Woven.

H3 = terdapat pengaruh positif variasi jarak pembebanan terhadap stabilitas lereng sebelum diperbaiki dengan Geotextile Woven.

H4 = terdapat pengaruh negatif variasi jarak pembebanan terhadap stabilitas lereng sebelum diperbaiki dengan Geotextile Woven.

H5 = terdapat pengaruh positif variasi kemiringan terhadap stabilitas lereng sesudah diperbaiki dengan Geotextile Woven.

H6 = terdapat pengaruh negatif variasi kemiringan terhadap stabilitas lereng sesudah diperbaiki dengan Geotextile Woven.

$\mathbf{H 7}=$ terdapat pengaruh positif variasi jarak pembebanan terhadap stabilitas lereng sesudah diperbaiki dengan Geotextile Woven.

H8 = terdapat pengaruh negatif variasi jarak pembebanan terhadap stabilitas lereng sesudah diperbaiki dengan Geotextile Woven.

\section{Penelitian Terdahulu}

\begin{tabular}{|c|c|c|}
\hline $\begin{array}{c}\text { Nama } \\
\text { Peneliti }\end{array}$ & Judul Penelitian & Hasil Penelitian \\
\hline $\begin{array}{l}\text { Ira Falkiya, } \\
\text { As'ad } \\
\text { Munawir, } \\
\text { Harimurti, } \\
2014\end{array}$ & $\begin{array}{l}\text { Pengaruh } \\
\text { Kemiringan } \\
\text { Lereng dan } \\
\text { Lebar Pondasi } \\
\text { dengan Rasio } \\
\text { d/B = 1 } \\
\text { Terhadap Daya } \\
\text { Dukung Pondasi } \\
\text { pada Pemodelan } \\
\text { Fisik Lereng }\end{array}$ & $\begin{array}{l}\text { Terjadi } \\
\text { peningkatan daya } \\
\text { dukung pondasi } \\
\text { menerus pada } \\
\text { lereng dengan } \\
\text { menggunakan } \\
\text { perkuatan } \\
\text { Geotextile } \\
\text { dibandingkan } \\
\text { dengan pada }\end{array}$ \\
\hline
\end{tabular}

\begin{tabular}{l|l|l}
\hline & $\begin{array}{l}\text { dengan } \\
\text { Perkuatan } \\
\text { Geotextile }\end{array}$ & $\begin{array}{l}\text { lereng tanpa } \\
\text { perkuatan. }\end{array}$ \\
& \\
& \\
& $\begin{array}{l}\square \text { Semakin besar } \\
\text { kemiringan lereng, } \\
\text { maka daya dukung } \\
\text { yang dihasilkan } \\
\text { akan semakin } \\
\text { menurun. }\end{array}$ \\
& \\
&
\end{tabular}

Sumber: Hasil kajian penulis, 2019.

\begin{tabular}{|c|c|c|}
\hline Nama Peneliti & $\begin{array}{c}\text { Judul } \\
\text { Penelitian }\end{array}$ & Hasil Penelitian \\
\hline \multirow{3}{*}{$\begin{array}{l}\text { Auliyah Rizky } \\
\text { Suhasmoro, } \\
\text { As'ad } \\
\text { Munawir, } \\
\text { Arief } \\
\text { Rachmansyah, } \\
2014\end{array}$} & \multirow{3}{*}{$\begin{array}{l}\text { Pengaruh } \\
\text { Kemiringan } \\
\text { Lereng Dan } \\
\text { Jarak Pondasi } \\
\text { Ke Tepi } \\
\text { Lereng } \\
\text { Terhadap } \\
\text { Daya Dukung } \\
\text { Pondasi Pada } \\
\text { Pemodelan } \\
\text { Fisik Lereng } \\
\text { Pasir Dengan } \\
\text { Perkuatan } \\
\text { Geotekstile }\end{array}$} & $\begin{array}{l}\square \text { Terjadi } \\
\text { peningkatan } \\
\text { daya dukung } \\
\text { pondasi } \\
\text { menerus pada } \\
\text { lereng dengan } \\
\text { menggunakan } \\
\text { perkuatan } \\
\text { geotekstil } \\
\text { dibandingkan } \\
\text { dengan pada } \\
\text { lereng tanpa } \\
\text { perkuatan. }\end{array}$ \\
\hline & & $\begin{array}{l}\square \text { Semakin } \\
\text { besar } \\
\text { kemiringan } \\
\text { lereng, maka } \\
\text { daya dukung } \\
\text { yang dihasilkan } \\
\text { akan semakin } \\
\text { menurun. }\end{array}$ \\
\hline & & $\begin{array}{l}\square \text { Semakin jauh } \\
\text { jarak pondasi } \\
\text { dari puncak } \\
\text { lereng, maka } \\
\text { daya dukung } \\
\text { yang dihasilkan } \\
\text { akan semakin } \\
\text { besar. }\end{array}$ \\
\hline
\end{tabular}

Sumber: Hasil kajian penulis, 2019. 


\section{METODELOGI PENELITIAN}

\subsection{Metode Penelitian}

Pengujian dalam penelitian ini dibedakan menjadi 2 macam model yaitu :

1. Pengujian Model I merupakan uji 2 variasi jarak pembebanan dan 3 variasi kemiringan tanah tanpa menggunakan perkuatan Geotextile Woven.

2. Pengujian Model II merupakan uji 2 variasi jarak pembebanan dan 3 variasi kemiringan tanah dengan menggunakan perkuatan Geotextile Woven.

\subsection{Analisa Data}

Dalam pengumpulan studi ini diperlukan data data yang mendukung baik itu data primer maupun data sekunder. Yang dimaksud data primer adalah data yang diperoleh dari pengukuran langsung di lapangan, sedangkan data sekunder adalah data yang bersumber dari instansi terkait dan pernah dilakukan pengukurannya dan data yang digunakan dalam tugas akhir ini adalah data sekunder.

\subsection{Flow Chart}

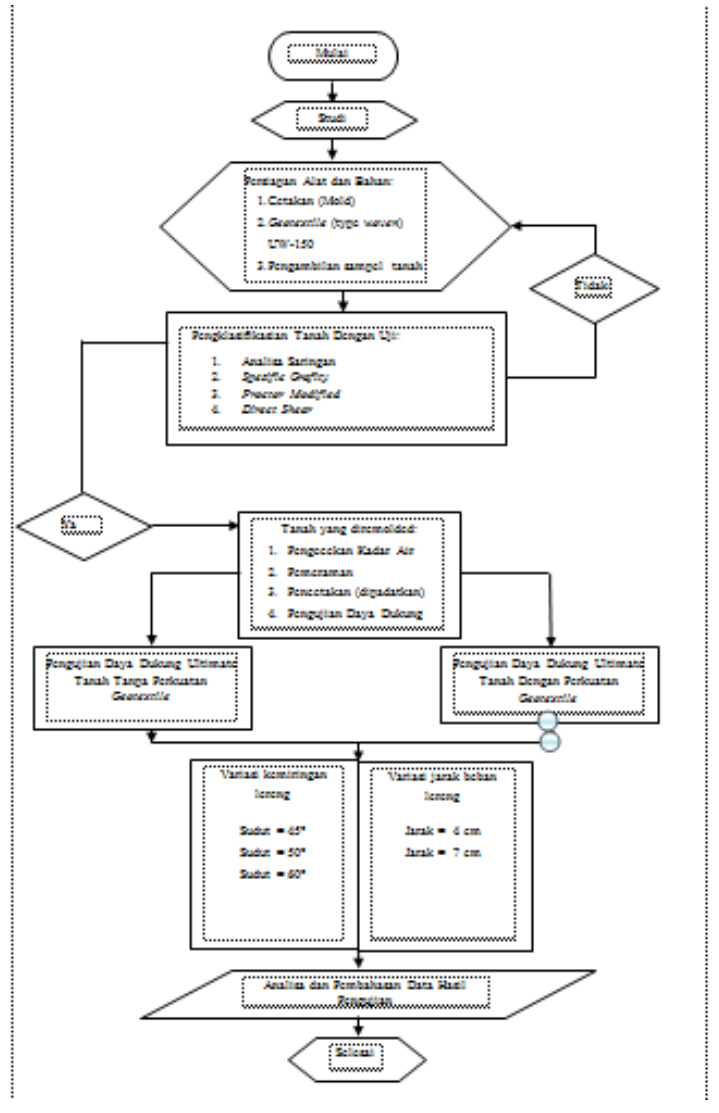

\section{ANALISA DAN PEMBAHASAN}

Penelitian pemodelan ini bertujuan untuk mengetahui stabilitas lereng dengan tinjauan 3 (tiga) variasi kemirigan, yaitu: $45^{\circ}, 50^{\circ}$, dan $60^{\circ}$ serta 2 (dua) variasi jarak beban yang bekerja pada lereng, yaitu: $4 \mathrm{~cm}$ dan $7 \mathrm{~cm}$. Pemodelan ini dilakukan pada cetakan ( $m o l d$ ) yang dibuat dengan desain sendiri dan pengujiannya dilakukan menggunakan alat CBR laboratorium dengan ketinggian pemodelan tanah $12 \mathrm{~cm}$. Dibawah ini merupakan gambaran proses pemodelan penelitian penulis:

1. Pemodelan pertama, pemodelan tanah sebelum diperbaiki menggunakan Geotextile Woven di uji dengan (1) tiga variasi kemiringan $45^{\circ}, 50^{\circ}$, dan $60^{\circ}(2)$ dua jarak pembebanan $4 \mathrm{~cm}$ dan $7 \mathrm{~cm}$.

2. Pemodelan kedua, pemodelan tanah sesudah diperbaiki menggunakan Geotextile Woven di uji dengan (1) tiga variasi kemiringan $45^{\circ}, 50^{\circ}$, dan $60^{\circ}(2)$ dua jarak pembebanan $4 \mathrm{~cm}$ dan $7 \mathrm{~cm} \mathrm{(3)}$ Geotextile Woven UW-150 dipasang setiap $4 \mathrm{~cm}$ dari tinggi pemodelan tanah dengan panjang berbeda setiap kemiringan. Panjang Geotextile setiap kemiringan lereng dijabarkan sebagai berikut : (1) sudut $45^{\circ}=$ panjang alas $15 \mathrm{~cm}$, panjang tekuk muka lereng 5,66 cm, dan panjang tekuk atas lapisan tanah $3,75 \mathrm{~cm}$ (2) sudut $50^{\circ}=$ panjang alas $15 \mathrm{~cm}$, panjang tekuk muka lereng $5,22 \mathrm{~cm}$, dan panjang tekuk atas lapisan tanah $3,75 \mathrm{~cm}$ (3) sudut $60^{\circ}=$ panjang alas $15 \mathrm{~cm}$, panjang tekuk muka lereng $4,62 \mathrm{~cm}$, dan panjang tekuk atas lapisan tanah $3,75 \mathrm{~cm}$.

\subsection{Pengujian Tanah Sebelum Pemodelan 4.1.1. Hasil Analisa Saringan}

Tabel 4.1. Hasil Analisa Saringan

\begin{tabular}{|l|c|c|c|c|c|}
\hline \multicolumn{2}{|l|}{ Nama Bahan } & \multicolumn{4}{|c|}{ PASIR } \\
\hline Berat Contoh (gr) & \multicolumn{4}{|c|}{ 500 } \\
\hline $\begin{array}{c}\text { Ukuran } \\
\text { Saringan }\end{array}$ & $\begin{array}{c}\text { Ukuran } \\
\text { Saringan }\end{array}$ & $\begin{array}{c}\text { Berat } \\
\text { Masing- } \\
\text { Masing } \\
\text { Tertahan }\end{array}$ & & $\begin{array}{c}\text { Prosentase } \\
\text { Jumlah } \\
\text { Tertahan }\end{array}$ & $\begin{array}{c}\text { Prosentase } \\
\text { Jumlah } \\
\text { Lolos }\end{array}$ \\
\hline (inch) & $(\mathbf{m m})$ & (gram) & (gram) & $\mathbf{( \% )}$ & $(\%)$ \\
\hline No. 4 & 4,75 & 0,00 & 0 & 0 & 100 \\
\hline No. 10 & 2 & 113,90 & 113,9 & 22,78 & 77,22 \\
\hline No. 20 & 0,85 & 182,30 & & 59,24 & 40,76 \\
\hline No. 40 & 0,425 & 136,30 & 432,5 & 86,50 & 13,50 \\
\hline No. 60 & 0,25 & 35,80 & 468,3 & 93,66 & 6,34 \\
\hline No. 140 & 0,106 & 19,50 & 487,8 & 97,56 & 2,44 \\
\hline No. 200 & 0,075 & 4 & 491,8 & 98,36 & 1,64 \\
\hline Pan & - & 8,20 & 500,0 & 100,00 & 0,00 \\
\hline
\end{tabular}


Menurut sistem klasifikasi AASTHO dari analisa saringan yang telah penulis lakukan didapatkan hasil dimana tanah termasuk pasir, terbukti dari banyak butiran tertahan di ukuran ayakan No. $10(2 \mathrm{~mm})=77,22 \%$, No. $20(0,85$ $\mathrm{mm})=40,76 \%$, No. $40(0,425 \mathrm{~mm})=13,50 \%$, No. $60(0,25 \mathrm{~mm})=6,34 \%$, No. $140(0,106$ $\mathrm{mm})=2,44 \%$, dan No. $200(0,075 \mathrm{~mm})=$ $1,64 \%)$.

\subsubsection{Hasil Pengujian Spesific Grafity}

Tabel 4.2. Hasil Pengujian Spesific Grafity LOLOS AYAKAN 40

\begin{tabular}{|l|c|c|c|c|}
\hline Specify Grafity (GS) & & & & \\
\hline No Bejana & & 1 & 2 & 3 \\
\hline Berat Bejana & gram & 172,70 & 175,00 & 168,40 \\
\hline Berat Bejana + Air (W1) & gram & 669,50 & 672,00 & 665,50 \\
\hline Berat Bejana + Air + Tanah (W2) & gram & 731,30 & 733,70 & 727,80 \\
\hline Berat Tanah Kering (W3) & gram & 100,00 & 99,20 & 99,70 \\
\hline Temperatur Campuran (T1 29' C) & C & 26,00 & 26,00 & 26,00 \\
\hline $\begin{array}{l}\text { GS (pada 29' C) = W3/ (W1+W3)- } \\
\text { W2 }\end{array}$ & & 2,62 & 2,65 & 2,67 \\
\hline Faktor Koresi, A & & 1,00 & 1,00 & 1,00 \\
\hline GS (pada 20' C) = A.GS (pada 29' C) & & 2,61 & 2,64 & 2,66 \\
\hline GS Rata-rata & & & 2,64 & \\
\hline
\end{tabular}

Didapatkan hasil uji Specify Grafity ratarata 2,64

\subsubsection{Hasil Pengujian Proctor}

Tabel 4.3. Hasil Pengujian Proctor

\begin{tabular}{|c|c|c|c|c|c|c|c|}
\hline $\begin{array}{c}\text { Kadar air } \\
\text { Prosentase (\%) }\end{array}$ & $\begin{array}{c}\text { Penamba } \\
\text { han air }\end{array}$ & & $\begin{array}{l}\text { Berat } \\
\text { Volum } \\
\text { e } \\
\text { Basah }\end{array}$ & $\begin{array}{c}\text { Berat } \\
\text { Volu } \\
\text { me } \\
\text { Basah } \\
- \\
\text { mold }\end{array}$ & $\begin{array}{c}\mathrm{Kad} \\
\text { ar } \\
\text { Air } \\
\text { Akh } \\
\text { ir }\end{array}$ & $\begin{array}{c}\text { Berat } \\
\text { Volu } \\
\text { me } \\
\text { tanah } \\
\text { Basah } \\
\text { ( ( ) }\end{array}$ & $\begin{array}{c}\text { Berat } \\
\text { Volu } \\
\text { me } \\
\text { Kerin } \\
\mathrm{g}(\mathrm{yd})\end{array}$ \\
\hline & $\%$ & gr & ton $/ \mathrm{m} 3$ & $\begin{array}{c}\text { ton } / \mathrm{m} \\
3\end{array}$ & $\%$ & & \\
\hline 1,55 & 0 & 0 & 11223 & 4246 & 1,54 & 1,603 & 1,578 \\
\hline 4,55 & 3 & $\begin{array}{c}206,7 \\
5\end{array}$ & 11828 & 4851 & 4,35 & 1,831 & 1,755 \\
\hline 6,55 & 5 & $\begin{array}{c}344,5 \\
8\end{array}$ & 11835 & 4858 & 6,07 & 1,834 & 1,729 \\
\hline 8,55 & 7 & $\begin{array}{c}482,4 \\
1\end{array}$ & 12048 & 5071 & 8,22 & 1,914 & 1,769 \\
\hline 10,55 & 9 & $\begin{array}{c}620,2 \\
4\end{array}$ & 12213 & 5236 & $\begin{array}{c}10,7 \\
0\end{array}$ & 1,976 & 1,785 \\
\hline 12,55 & 11 & $\begin{array}{c}758,0 \\
7 \\
\end{array}$ & 12179 & 5202 & $\begin{array}{c}12,2 \\
3\end{array}$ & 1,963 & 1,750 \\
\hline 16,55 & 15 & $\begin{array}{c}1033, \\
73\end{array}$ & 12194 & 5217 & $\begin{array}{c}15,3 \\
3\end{array}$ & 1,969 & 1,707 \\
\hline 10,50 & 9 & $\begin{array}{c}616,8 \\
0 \\
\end{array}$ & $\begin{array}{c}\text { untuk } \\
\text { cbr }\end{array}$ & & & & \\
\hline
\end{tabular}

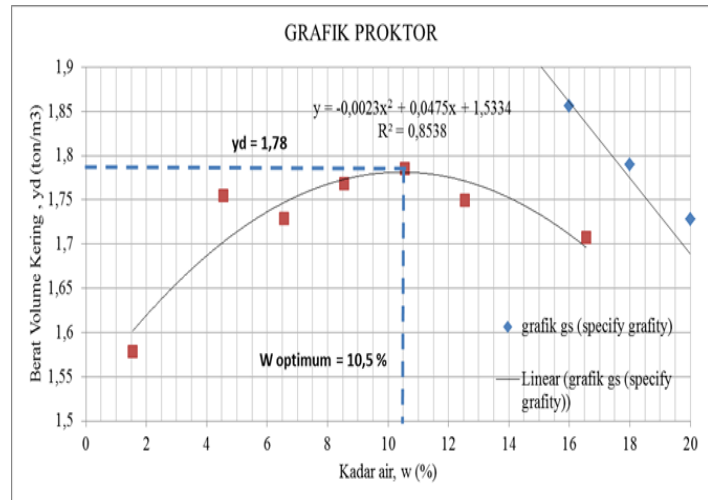

Gambar 4.1 Grafik Proctor

Dari grafik diatas bisa diketahui untuk mencapai kepadatan tanah kering ( $\Upsilon \mathrm{d}$ ) sebesar $1,78 \mathrm{gr} / \mathrm{cm} 3$ dibutuhkan kadar air tanahnya sebesar $10,5 \%$.

\subsubsection{Hasil Pengujian Direct Shear}

Tabel 4.4. Hasil Pengujian Direct Shear

\begin{tabular}{|c|c|c|c|c|c|c|c|}
\hline Yd & Satuan & w & Satuan & $\Phi$ & Satuan & $\mathrm{c}$ & Satuan \\
\hline 1,78 & $\mathrm{gr} / \mathrm{cm}^{3}$ & 10,5 & $\%$ & 41,11 & 0 & 0,09 & $\mathrm{~kg} / \mathrm{cm}^{2}$ \\
\hline 1,78 & $\mathrm{gr} / \mathrm{cm}^{3}$ & 10,5 & $\%$ & 48,99 & 0 & 0,082 & $\mathrm{~kg} / \mathrm{cm}^{2}$ \\
\hline 1,78 & $\mathrm{gr} / \mathrm{cm}^{3}$ & 10,5 & $\%$ & 40,15 & 0 & 0,166 & $\mathrm{~kg} / \mathrm{cm}^{2}$ \\
\hline 1,63 & $\mathrm{gr} / \mathrm{cm}^{3}$ & 2,1 & $\%$ & 25,77 & 0 & 0,13 & $\mathrm{~kg} / \mathrm{cm}^{2}$ \\
\hline 1,63 & $\mathrm{gr} / \mathrm{cm}^{3}$ & 2,1 & $\%$ & 35,44 & 0 & 0,08 & $\mathrm{~kg} / \mathrm{cm}^{2}$ \\
\hline 1,57 & $\mathrm{gr} / \mathrm{cm}^{3}$ & 1 & $\%$ & 14,33 & 0 & 0,24 & $\mathrm{~kg} / \mathrm{cm}^{2}$ \\
\hline
\end{tabular}

Setelah dilakukan beberapa penelitian penulis menabelkan data seperti diatas. Penulis mengambil data yang dipakai untuk pemodelan penelitian ini sebagai berikut: $\Upsilon \mathrm{d}=1,78$ gr $/ \mathrm{cm} 3$, kadar air $(\mathrm{w})=10,5 \%$, sudut geser $\operatorname{tanah}(\Phi)=41,11^{\circ}$, dan kohesi atau gaya tarik antar butiran tanah $(\mathrm{c})=0,09 \mathrm{~kg} / \mathrm{cm} 2$.

\subsection{Analisa dan Perhitungan}

\subsubsection{Jarak $4 \mathrm{~cm}$ dan $7 \mathrm{~cm}$ Pada Sudut $45^{\circ}, 50^{\circ}$, dan $60^{\circ}$ Sebelum Tanah Diperbaiki Menggunakan Geotextile.}

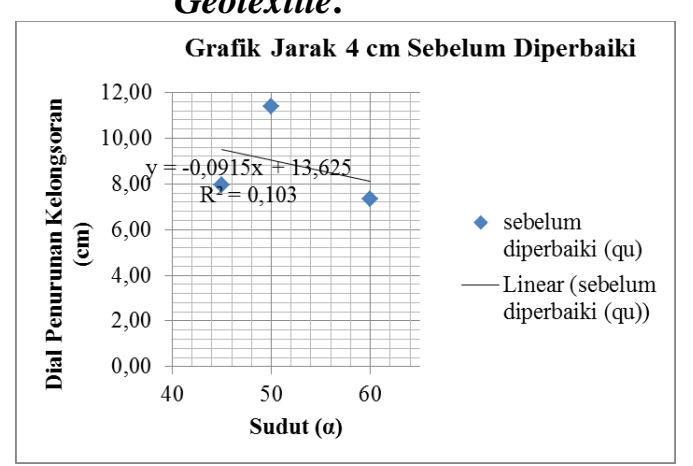


Gambar 4.2. Grafik Jarak 4 cm Sebelum Diperbaiki

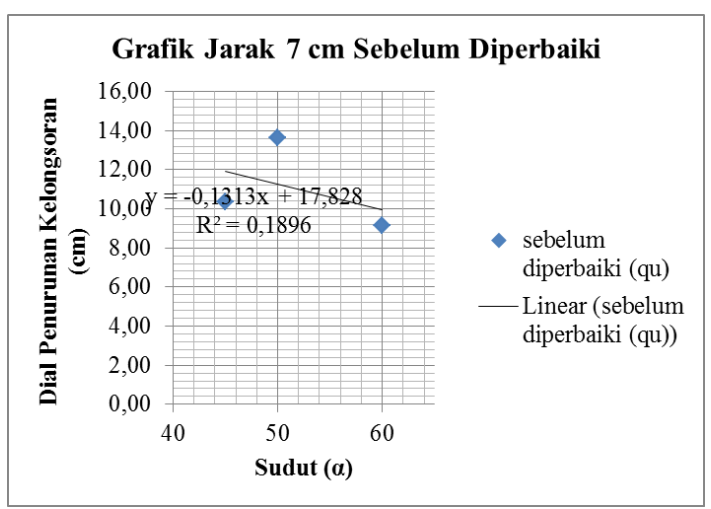

Gambar 4.3. Grafik Jarak $7 \mathrm{~cm}$ Sebelum Diperbaiki

Dari grafik 4.2. dan 4.3. dapat diketahui bahwa semakin jauh jarak pembebanan dari bibir lereng dan semakin kecil sudut kelerengannya, didapatkan hasil daya dukung tanah besar yang dikorelasikan dengan kekakuan tanah.

\subsubsection{Jarak $4 \mathrm{~cm}$ dan $7 \mathrm{~cm}$ Pada Sudut $45^{\circ}, 50^{\circ}$, dan $60^{\circ}$ Sesudah Tanah Diperbaiki Menggunakan Geotextile.}

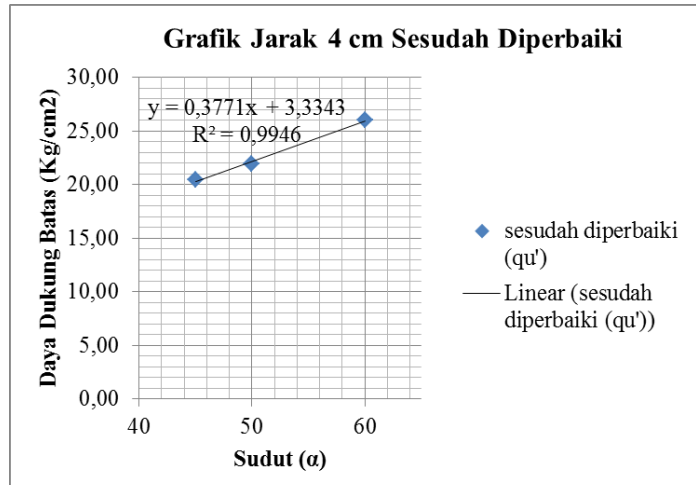

Gambar 4.4. Grafik Jarak 4 cm Sesudah Diperbaiki

Dari grafik 4.4. dan 4.5. dapat diketahui bahwa semakin jauh jarak pembebanan dari bibir lereng dan semakin besar sudut kelerengannya, didapatkan hasil daya dukung tanah kecil yang dikorelasikan dengan kekakuan tanah.

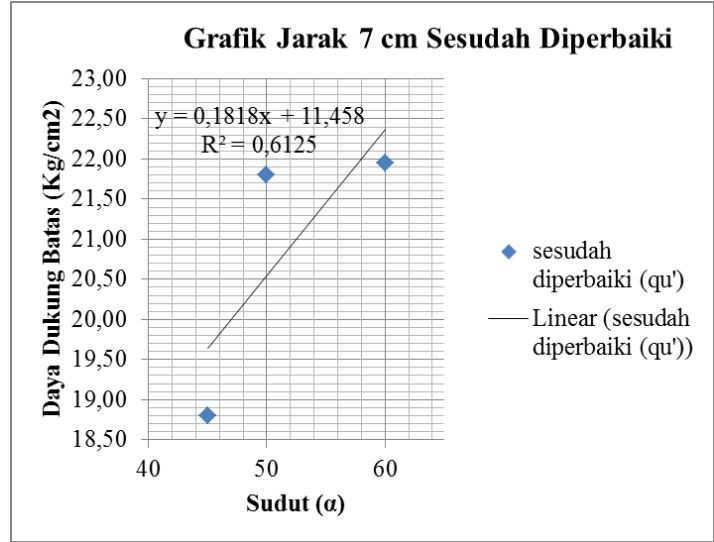

Gambar 4.5. Grafik Jarak 7 cm Sesudah Diperbaiki

\subsubsection{Perhitungan Menurut Parameter BCI (Bearing Capacity Improvement)}

Pengujian ini bertujuan mendapatkan nilai BCI dari masing-masing benda uji, dimana BCI itu sendiri ditinjau dari nilai hasil uji tanah sebelum diperbaiki (qu) dan tanah sesudah diperbaiki (qu'). Dengan rumus sebagai berikut:

Keterangan:

$$
B C I=\frac{q u^{\prime}}{q u}
$$

- $\mathrm{qu}^{\prime}=$ tanah sesudah diperbaiki dengan Geotextile

- $\mathrm{qu}=$ tanah sebelum diperbaiki dengan Geotextile

Dari hasil pengujian didapatkan nilai BCI per masing-masing sudut dan jarak sebagai berikut:

Tabel 4.5. Tabel Perhitungan BCI

\begin{tabular}{|c|c|c|c|c|c|}
\hline \multirow{2}{*}{ No } & \multirow{2}{*}{ Sudut } & \multirow{2}{*}{$\begin{array}{c}\text { Jarak } \\
\text { Beban } \\
(\mathrm{cm})\end{array}$} & $\begin{array}{c}\text { Daya Dukung } \\
\text { Batas Sebelum } \\
\text { Perbaikan (qu) }\end{array}$ & $\begin{array}{c}\text { Daya Dukung } \\
\text { Batas Sesudah } \\
\text { Perbaikan (qu') }\end{array}$ & \multirow{2}{*}{ BCI (qu'/qu) } \\
\cline { 4 - 5 } & & 4 & 7,95 & 20,46 & 2,575 \\
\hline 1 & $45^{\circ}$ & 4 & 10,35 & 18,80 & 1,817 \\
\hline 2 & & 7 & 11,39 & 21,95 & 1,927 \\
\hline 3 & $50^{\circ}$ & 4 & 13,61 & 21,80 & 1,601 \\
\hline 4 & & 7 & 7,36 & 26,04 & 3,540 \\
\hline 5 & $60^{\circ}$ & 4 & 9,16 & 21,95 & 2,395 \\
\hline 6 & & 7 & & & \\
\hline
\end{tabular}

Dari Tabel 4.5. Tabel Perhitungan BCI penulis kemudian menyajikan dalam bentuk grafik dibawah ini: 


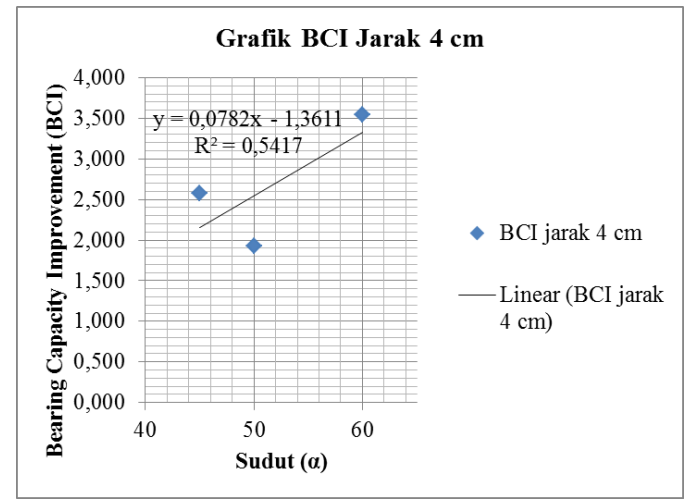

Gambar 4.6. Grafik BCI Jarak $4 \mathrm{~cm}$

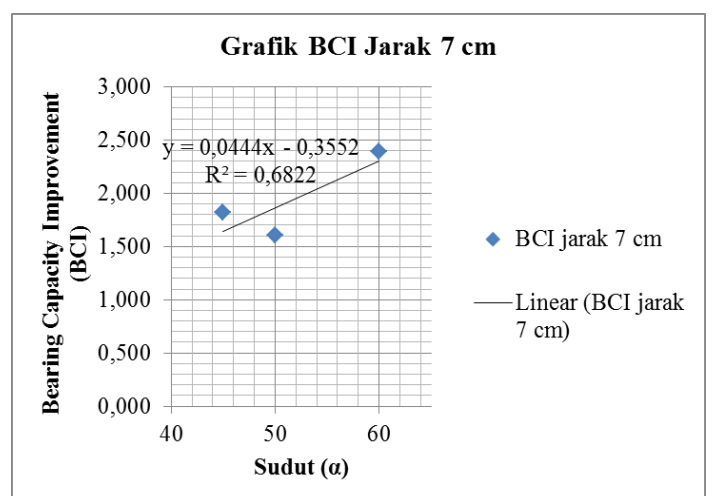

Gambar 4.7. Grafik BCI Jarak $7 \mathrm{~cm}$

Dari grafik 4.6. dan 4.7. dapat disimpulkan bahwa semakin jauh jarak pembebanan terhadap bibir lereng, maka semakin kecil nilai BCInya.

Pembahasan diatas bisa di analogikan bahwa perbaikan tanah lereng dengan menggunakan Geotextile mempunyai sifat memperkaku tanah yang mana semakin besar sudut kelerengan maka semakin kaku.

\subsubsection{Hasil BCI Menurut SPSS Regresi Linear Berganda}

Hasil penelitian yang telah penulis lakukan dihitung dengan SPSS untuk mendapatkan nilai Rasio (R) sebagai berikut:

Tabel 4.6. Nilai Rasio (R)

\begin{tabular}{|c|c|c|c|c|c|}
\hline $\begin{array}{c}\text { Mode } \\
1\end{array}$ & $\mathrm{R}$ & R Square & $\begin{array}{l}\text { Adjusted R } \\
\text { Square }\end{array}$ & $\begin{array}{l}\text { Std. Error of } \\
\text { the Estimate }\end{array}$ & $\begin{array}{l}\text { Durbin- } \\
\text { Watson }\end{array}$ \\
\hline 1 & $.888^{\mathrm{a}}$ & ,788 &, 717 & 1,13137 & 2,059 \\
\hline
\end{tabular}

Dari hasil perhitungan dengan SPSS didapatkan nilai rasio $(\mathrm{R})$ atau $\mathrm{R}$ Square adalah $0,788=78,8 \%$ yang dimana variabel bebas : variasi kemiringan dan variasi jarak pembebanan berpengaruh $78,8 \%$ dari variabel terikat yaitu BCI.

\section{KESIMPULAN DAN SARAN}

\subsection{Kesimpulan}

Berdasarkan hasil penelitian ini penulis menyimpulkan:

1. Pada pemodelan tanah sebelum diperbaiki menggunakan Geotextile dapat diketahui bahwa semakin kecil sudut kelerengannya, maka daya dukung tanah yang dikorelasikan dengan kekakuan tanah bernilai besar. Sedangkan pada pemodelan tanah sesudah diperbaiki menggunakan Geotextile semakin kecil sudut kelerengannya, maka daya dukung tanah yang dikorelasikan dengan kekakuan tanah bernilai kecil.

2. Pada pemodelan tanah sebelum diperbaiki menggunakan Geotextile dapat diketahui bahwa semakin jauh jarak pembebanan dari bibir lereng, maka daya dukung tanah yang dikorelasikan dengan kekakuan tanah bernilai besar. Sedangkan pada pemodelan tanah sesudah diperbaiki menggunakan Geotextile semakin jauh jarak pembebanan dari bibir lereng, maka daya dukung tanah yang dikorelasikan dengan kekakuan tanah bernilai kecil.

\subsection{Saran}

1. Sebelum penelitian dilakukan sebaiknya studi literatur penelitian terdahulu, kalau ada. Studi literatur penelitian terdahulu bertujuan apabila tinjauan sama dengan judul yang ditinaju sehingga kita bisa mengembangkan dan mendukung penelitian terdahulu.

2. Diperlukan beberapa kali pengujian untuk mendapatkan hasil yang maksimal.

3. Penelitian ini bisa dikembangkan dengan tinjaun lainnya, sehingga bisa mendukung penelitian yang dilakukan oleh penulis. 


\section{DAFTAR PUSTAKA}

Auliyah Rizky Suhasmoro, As'ad Munawir, Arief Rachmansyah. (2014). Pengaruh Kemiringan Lereng Dan Jarak Pondasi Ke Tepi Lereng Terhadap Daya Dukung Pondasi Pada Pemodelan Fisik Lereng Pasir Dengan Perkuatan Geotekstile, 1-9. Jurnal terpublikasi : Jurusan Teknik Sipil Universitas Brawijaya Malang.

Das, Braja M. 1984. Mekanika Tanah (PrinsipPrinsip Rekayasa Geoteknis) Jilid 2. Jakarta: Erlangga.

Das, Braja M. 1998. Mekanika Foundation Engineering, Fourth Edition. New York: PWS Publishing.

Ira Falkiya, As'ad Munawir, Harimurti. (2014). Pengaruh Kemriringan Lereng dan Lebar Pondasi dengan Rasio $d / B=$ Terhadap Daya Dukung Pondasi Pada Pemodelan Fisik Lereng dengan Perkuatan Geotextile, 1-9. Jurnal terpublikasi : Jurusan Teknik Sipil Universitas Brawijaya Malang. 